\title{
THE ASPECTS OF IMPROVING TEACHER'S PROFESSIONAL ACTIVITY ORIENTED TOWARDS THE LEARNER'S WELLBEING AND SUCCESS
}

\author{
Asta Rauduvaitè \\ Vytautas Magnus University, Vilnius \\ Greta Šadeikytè \\ Vytautas Magnus University, Vilnius
}

\begin{abstract}
Education today is going through an important period which is marked by changes, therefore, it is essential to consider the needs of the changing society. It calls for a new attitude towards modelling of the educational process that focuses on the learner's wellbeing and personal success, i.e., the emphasis is laid on its efficiency, which enables the learner to pursue good learning outcomes. Targeting at the goals of general education during the music lesson, the teacher considers the peculiarities of the learners' developmental period, individual specifics of their attention, perception, thinking and emotional development as well as their inclinations and interests. The teacher also searches for the appropriate educational methods or their combinations. Therefore, on the basis of the conducted research, attempts are made to highlight and create strategies that can contribute to revealing socio-educational factors that can result in successful learning and wellbeing of a learner. The research problem is formulated as the question: what factors can have influence on improvement of music teacher's pedagogical activity while focusing on the learner's wellbeing and his/her success in the process of education? The goal of the research: to reveal possibilities for improving music teachers' pedagogical activity that focuses on the learner's wellbeing and success in a school of general education. The research revealed that achievements in innovative educational research direct the teacher towards successful participation in the processes of music education development and dissemination.
\end{abstract}

Keywords: music education, music teacher, learner.

\section{Introduction}

Education of pupils in schools is one of the areas where the main goals of the education reform are being implemented, i.e., the emphasis is laid on enabling the learners to comprehensively develop their physical, mental and spiritual qualities, to unfold their personality that would cherish meaningful values (The National Education Strategy for the Period of 2013-2022, 
2014). The Order of the Minister of Education and Science of the Republic of Lithuania No. V-683 On the Approval of the Description of Teacher Education Model (2017) targets at reforming the system of teacher training and qualification by training teachers who constantly develop professionally and work efficiently, teachers as members of the system of education who are motivated, flexible, not afraid of challenges and innovation. Different roles of the teacher are emphasized - a researcher; a person able to get to know the learner and cherish his/her powers; in the context of global changes, a creator of educational interaction and innovative content; a learner's advisor and consultant; a provider of pedagogical help in case of inclusive education; etc. In this context, educational documents respond to the needs of personal, societal and state development to foster an independent person for the future - flexible, open, responsible, creating, able to solve problems and adapt to the changing conditions of the environment (Education and training in Europe, 2020; Descriptor of Professional Competences of a Teacher, 2007; On the Approval of the Description of Requirements for Teacher Qualification, 2014). All the important factors mentioned above predetermine the attractiveness and prestige of the pedagogical profession, moreover, they precondition teaching/learning outcomes.

Transforming educational research has been undergoing social, technological and cultural changes, which call for a new attitude towards modelling of the educational process that focuses on the learner's wellbeing and personal success. The pedagogical interaction between the learner and the teacher and a two-way dialogue are perceived as a condition for engaging the learner into successful educational activity, encouraging him or her to discover, learn and create. Communication between the teacher and the learner play a significant role, where the interaction takes place and information is exchanged. Music education in such a context is a rather specific discipline encompassing the theoretical content together with a wide range of musical practice, during which not only musical abilities but also aesthetic, emotional components a well as those of feelings and intelligence are developed. Therefore, the success of the teacher relies on a versatile meaningful musical activity, whose relevance has been investigated by numerous music educologists from different countries: Heimonen, Herbert (2019), Sepp, et al (2019), Davidova, et al (2017), Hedden (2017), Hofer (2017), Sakadolskienè (2017), Vitkauskas, et al. (2012), Girdzijauskas (2012) and others. The research problem is formulated as the question: what factors can have influence on improvement of music teacher's pedagogical activity while focusing on the learner's wellbeing and his/her success in the process of education? The goal of the research: to reveal possibilities for improving music teachers' pedagogical activity that focuses on the learner's wellbeing and success in a school of general education. 


\section{Music Teachers in the Context of Changing Education Paradigms}

The role of the music teacher is not limited to passing on knowledge in the music lesson, the teacher is the one who fosters the learners' wider interests, search for information not only within the scope of the school but also outside it. Music content changes due to the changes in social and cultural life, increase of media influence and changing values. The learners openly accept modern information, which does not always form a favourable, aesthetic perception of music. Therefore, challenges of the changing society provoke music teachers to orient in a changing environment, to search for diverse methods that ensure increased interest of the learner as well as develop his/her personality. According to Rinkevičius (2002), in order to successfully develop learners' abilities of musical thinking and musical culture, it is essential that the teacher should not only consider himself/herself to be a disseminator of information, but also a creator of a personality.

According to Johnson and Mattheuws (2017), the teacher's pedagogical activity can be divided into three stages: planning, instructing and reflecting. Reflective teacher's thinking is of key importance in the proper choice of flexible teaching methods that meet the learners' needs. In their research conducted, Powell and Parker (2017) refer to an image of a successful teacher possessing qualities such as taking care of pupils, being honest, having a good sense of humour, being able to manage time and energy, feeling self-confident, being joyful, humble, patient and consistent in his/her professional activity. Besides, a successful music teacher does not distinguish between professional and everyday life. Lasauskienè (2010) claims that the teacher's ability to work in diverse teaching/learning environments, dissemination of new ideas, appreciation of a learner's knowledge and achievements, search for innovative teaching methods are constituents of the teacher's main mission. Therefore, the teacher performs various functions in the educational process, such as diagnosing, planning, assessing, organizing, etc.

The teacher develops own artistic and pedagogical powers while developing himself or herself, thus, he/she is capable of optimizing the educational process and as a result, simultaneously develops own personality (Vitkauskas, 2001). Moreover, Strakšienė (2004) states that the type of the music teacher makes influence on cooperation in the music lesson, as it has been noticed that the personality type of a music teacher can predetermine the success of the learners. Abramauskiene and Kirliauskiene (2014) claim that the music teacher is supposed to not only be good at the subject field but also have comprehensive erudition of musical culture, since the subject of music encompasses a wide range of 
musical experiences (from psychomotor skills to aesthetic relationship with music). Therefore, it is important to develop a deeper and more meaningful learner's relationship with music. The content of music education should encourage the learner to discover, show interest, think creatively, perceive and interpret, since the learner's wellbeing and success of music education depend on that.

\section{Methods}

The national survey "Pedagogical activity of the contemporary music teacher in a Lithuanian general education school: state and possibilities for improving" was conducted in Lithuania in 2016-2018 with the aim to identify and evaluate the peculiarities of the music teacher's professional activity, to foresee strategies for the improvement of the professional development of music teachers as well as those for the training of music teachers with the focus on the wellbeing and success of the learner. The information was obtained from teachers, school heads, learners and parents, whereas this article presents the results of an online survey of music teachers. The research sample embraced 306 music teachers from general education schools in Lithuania; they teach at institutions of primary, basic (lower secondary) and upper secondary education. Scientific recommendations how to target the research at the wellbeing of the subject that were provided by Bitinas (2006), Žydžiūnaite and Sabaliauskas (2017) were referred to while conducting the research. The data obtained were carefully examined; they are authentic, probable, valid and reliable.

The methods of the research: Data collection: integrative analysis of scientific literature and educational documents; written questionaire survey of music teachers. Data analysis: statistical analysis of research data using a statistical data processing software; qualitative content analysis.

The questionnaire survey method was used to conduct the reseach, where the compiled questionnaire employed in the research process encompassed questions related to planning and organization of the music lesson; teaching and learning; help to the learner; assessment; relationships, procedure and class management; and learning environment. The questionnaire consisted of 70 statements that can be answered by choosing one of the provided options: agree, partially agree, disagree. It also included questions aiming to characterize the respondent's age, education, working experience, qualification category, size of the school, type and location of the educational institution. 


\section{Results and discussion}

The analysis of the characteristics of the survey respondents revealed that the majority of them are music teachers aged between 41-50 years old. Data analysis also disclosed that their working experience ranges mainly from 15 to 25 years, that music teachers have a university degree and the distribution of the qualification category between a senior teacher and a teacher methodologist is almost the same. Since the quantitative research was conducted by carrying out a questionnaire survey in Lithuania, the information related to the location (city, town, village) of the respondents was also included. The majority of the teachers who participated in the survey work in the city. The research targeted at music teachers of primary, basic (lower secondary) and upper secondary schools of general education but the analysis of the results shows that the majority of the respondents work in gymnasiums. Although the participants of the survey teach in general education institutions of a different size, the majority of them work in schools with the number of learners ranging from 200 to 500.

The online survey of the research conducted aimed to ascertain music teachers' pedagogical activity in general education schools, problems that emerge, possibilities for improving, therefore, the teachers were inquired about organization and planning of music lessons. (Table 1).

Table 1. Planning and organizing a music lesson: insights into how to improve the teacher's pedagogical activity (in per cent)

\begin{tabular}{|l|c|c|c|}
\hline \multicolumn{1}{|c|}{ Statements } & Agree & $\begin{array}{c}\text { Partially } \\
\text { agree }\end{array}$ & Disagree \\
\hline $\begin{array}{l}\text { I rely on educational documents that regulate music } \\
\text { education }\end{array}$ & 74.5 & 23.9 & 1.0 \\
\hline $\begin{array}{l}\text { I feel responsible for the outcomes of my pedagogical } \\
\text { activity }\end{array}$ & 98.0 & 1.3 & 0 \\
\hline $\begin{array}{l}\text { Teaching/learning objectives, educational content, } \\
\text { methods and teaching aids are compatible in my lesson }\end{array}$ & 76.8 & 21.9 & 1.0 \\
\hline $\begin{array}{l}\text { The teaching methods I apply correspond to the age, } \\
\text { experience, capacities and needs of the learners }\end{array}$ & 84.6 & 14.4 & 0.7 \\
\hline $\begin{array}{l}\text { I formulate objectives of the lesson exactly and clearly } \\
\text { so that the learners can understand them }\end{array}$ & 81 & 18.3 & 0.7 \\
\hline $\begin{array}{l}\text { I plan music lessons including elements of } \\
\text { "unexpectedness and creativity" }\end{array}$ & 58.2 & 40.8 & 1.0 \\
\hline $\begin{array}{l}\text { I plan the content of music lessons taking into } \\
\text { consideration the learners' progress, musical skills and } \\
\text { needs of a particular group }\end{array}$ & 80.7 & 19 & 0.3 \\
\hline $\begin{array}{l}\text { I plan integrated assignments and activities together } \\
\text { with teachers of other subjects }\end{array}$ & 41.5 & 49.7 & 8.5 \\
\hline
\end{tabular}


The analysis of the research data reveals that music teachers feel responsible for the outcomes of their pedagogical activity (98.0 per cent of the respondents indicated the option of "agree") and rely on educational documents that regulate music education (74.5 per cent correspondingly). The research disclosed that teachers plan the content of music lessons taking into consideration the skills of a particular class of learners (80.7 per cent) and apply teaching methods that correspond to the age and experience of their learners (84.6 per cent). It is noticeable that nearly a half of the teachers who participated in the survey (49.7 per cent of the respondents indicated the option of "partially agree") less often integrate music lessons with other subjects or plan integrated assignments in their own lessons. Only 58.2 per cent of the respondents plan music lessons including elements of "unexpectedness and creativity". However, no matter how active the teacher may be, if the learners are even occasionally prevented from taking over the initiative, it is hardly possible to expect interesting and independent solutions made by learners themselves as well as performance-oriented success of the pupil (Girdzijauskienè, 2008; Šečkuvienè, 2004). Creative activity is primarily related to the learners' ability to independently perceive the problem and look for the ways to solve it.

The research also aimed at disclosing aspects of improving teaching (Table 2).

Table 2. Teaching: insights into how to improve the teacher's professional activity (in per cent)

\begin{tabular}{|l|c|c|c|}
\hline \multicolumn{1}{|c|}{ Statements } & Agree & $\begin{array}{c}\text { Partially } \\
\text { agree }\end{array}$ & Disagree \\
\hline I integrate music with other subjects & 60.1 & 37.9 & 1.6 \\
\hline $\begin{array}{l}\text { I relate musical activities with everyday experience and } \\
\text { interests of the learners }\end{array}$ & 65.7 & 32.4 & 1.6 \\
\hline $\begin{array}{l}\text { I apply teaching/learning methods that aim at } \\
\text { consolidating learning }\end{array}$ & 75.8 & 22.5 & 0.3 \\
\hline $\begin{array}{l}\text { I employ feedback methods so that to reflect pupils' } \\
\text { learning }\end{array}$ & 67.3 & 30.4 & 1.3 \\
\hline $\begin{array}{l}\text { I foresee which learner or group of learners may need } \\
\text { help while doing the tasks and prepare for this in } \\
\text { advance }\end{array}$ & 52.0 & 44.8 & 2.3 \\
\hline $\begin{array}{l}\text { When the learners work either individually or perform } \\
\text { tasks in pairs or groups, they are well aware of the rules } \\
\text { and process of such forms of work }\end{array}$ & 68.3 & 30.4 & 1.0 \\
\hline $\begin{array}{l}\text { I select information relevant to music education from } \\
\text { various sources of information }\end{array}$ & 84 & 15 & 0.7 \\
\hline $\begin{array}{l}\text { Learners in my lessons assume the role of the teacher } \\
\text { (e.g., they become partners, consultants, advisers, } \\
\text { mediators, planners, experts) }\end{array}$ & 34 & 60.1 & 5.2 \\
\hline
\end{tabular}




\begin{tabular}{|l|c|c|c|}
\hline \multicolumn{1}{|c|}{ Statements } & Agree & $\begin{array}{c}\text { Partially } \\
\text { agree }\end{array}$ & Disagree \\
\hline $\begin{array}{l}\text { I assign homework tasks to deepen and consolidate } \\
\text { the material acquired during the lesson }\end{array}$ & 30.7 & 44.8 & 21.9 \\
\hline $\begin{array}{l}\text { I consistently teach according to the textbook in my } \\
\text { lessons }\end{array}$ & 9.2 & 53.6 & 36.6 \\
\hline The learners use workbooks & 19.9 & 34.3 & 44.8 \\
\hline
\end{tabular}

As indicated in Table 2, music teachers apply teaching/learning methods that aim at consolidating learning (75.8 per cent of the respondents) and reflect at the end of the lesson (67.3 per cent). The respondents point out that they collect information from various sources while preparing for lessons (84 per cent). However, 44.8 per cent of the participants in the survey state that their pupils do not use workbooks. More than 50 per cent of the teachers teach according to the textbook inconsistently, only 30.7 per cent of the respondents claim that they assign homework tasks to consolidate the material acquired during the lesson. The results of the study suggest that teachers take into consideration the needs and experience of the learners. However, the teacher is supposed to be a facilitator, a counsellor who provides the pupils with information and tools, a person who assists in foreseeing possible ways of problem solution, a one who plans and organizes a successful performance of the learners (Hallam, 2010). Therefore, it is possible to claim that the teachers are in constant pursue of new materials, they strive to employ a diversity of teaching methods, they evaluate the content and asses the outcomes of their work, i.e., they try model the educational process with focus on the learner's wellbeing and personal success.

Aspects of organization of the learning process, the results of which are provided in Table 3, were also analysed in the research.

Table 3. Learning: insights into how to improve the teacher's pedagogical activity (in per cent)

\begin{tabular}{|l|c|c|c|}
\hline \multicolumn{1}{|c|}{ Statements } & Agree & $\begin{array}{c}\text { Partially } \\
\text { agree }\end{array}$ & Disagree \\
\hline $\begin{array}{l}\text { I encourage learners to ask questions and get fully } \\
\text { involved in the activities in the classroom }\end{array}$ & 84.3 & 15 & 0.3 \\
\hline $\begin{array}{l}\text { I formulate tasks that promote problem-based learning } \\
\text { and learning through experience }\end{array}$ & 49.3 & 45.1 & 4.2 \\
\hline $\begin{array}{l}\text { My lesson opens up possibilities for creative self- } \\
\text { expression }\end{array}$ & 62.4 & 35.9 & 0.3 \\
\hline $\begin{array}{l}\text { The pupils learn how to cooperate with each other } \\
\text { during my lessons }\end{array}$ & 71.2 & 27.8 & 0 \\
\hline
\end{tabular}


The analysis of the results shows that the respondents encourage their learners to get fully involved in the classroom activities, to engage in a dialogue, music teachers create possibilities for the learners to develop their self-expression through creative activities. 71.2 per cent of the survey participants claim that their pupils learn how to cooperate with each other during the lesson. On the other hand, only 49.3 per cent of the respondents formulate tasks that promote problem-based learning and learning through experience. Based on the data collected in the survey it is possible to claim that the development of pupils' critical thinking and communication skills in the music lesson remains a relevant issue (General programmes of primary and basic (lower secondary) education, 2009).

Moreover, the respondents were asked to evaluate the statements related to the area of help for the learner, therefore, Table No. 4 presents insights into the improvement of the aspect in question.

Table 4. Help for the learner: insights into how to improve the teacher's pedagogical activity (in per cent)

\begin{tabular}{|l|c|c|c|}
\hline \multicolumn{1}{|c|}{ Statements } & Agree & $\begin{array}{c}\text { Partially } \\
\text { agree }\end{array}$ & Disagree \\
\hline $\begin{array}{l}\text { I assign tasks of different complexity taking into } \\
\text { consideration different musical skills and capacities of } \\
\text { the learners }\end{array}$ & 53.3 & 44.4 & 1.6 \\
\hline $\begin{array}{l}\text { I provide feedback to the learners related to their } \\
\text { individual achievements }\end{array}$ & 74.2 & 24.5 & 0.7 \\
\hline $\begin{array}{l}\text { I prepare additional tasks for the more gifted learners, } \\
\text { I foresee ways for individual self-dependent learning } \\
\text { together with a pupil }\end{array}$ & 47.7 & 46.1 & 5.2 \\
\hline $\begin{array}{l}\text { My remarks are directed towards the work done by } \\
\text { the learner, not to the person }\end{array}$ & 87.6 & 11.1 & 1 \\
\hline $\begin{array}{l}\text { I provide the learners with an opportunity to self- } \\
\text { correct their mistakes }\end{array}$ & 80.1 & 19.0 & 0.3 \\
\hline I develop self-esteem and self-confidence of the learners & 87.6 & 11.4 & 0.7 \\
\hline $\begin{array}{l}\text { I combine the aims, objectives and teaching methods } \\
\text { with the individual needs of the learners }\end{array}$ & 53.6 & 43.8 & 2.0 \\
\hline $\begin{array}{l}\text { I plan additional work for the learners with special } \\
\text { educational needs }\end{array}$ & 49.3 & 42.5 & 7.2 \\
\hline $\begin{array}{l}\text { The learners have a possibility to develop their own } \\
\text { musical skills when taking part in various projects, } \\
\text { concerts and festivals }\end{array}$ & 88.9 & 10.1 & 0.7 \\
\hline $\begin{array}{l}\text { More gifted or more experienced learners provide help } \\
\text { for those who need it }\end{array}$ & 76.8 & 20.9 & 1.6 \\
\hline
\end{tabular}

According to the survey results (Table 4), nearly 89 per cent of the respondents affirm that their learners develop own musical skills in the music lesson and participate in various educational activities of music. 
Less than a half of the survey participants prepare additional tasks for the more gifted learners, promote self-dependent learning, plan additional work for the learners with special educational needs. On the other hand, a significant number of the respondents (76.8 per cent) claim that they create conditions for the learners with more experience in music to help their classmates, thus, the cooperation among the pupils is developed.

The research data analysis also showed that music teachers seek to develop their pupils' self-confidence and self-esteem, encourage them to notice the mistakes made and analyse them in the music lesson. It is worth highlighting that the respondents state that they evaluate their pupils for the work done, not as a person (87.6 per cent). Approximately 75 per cent of the survey participants provide feedback to the learners related to their individual achievements during the lesson, i.e., successful learning and wellbeing of the learner are given considerable attention.

Nevertheless, the analysis of the study data preconditions the need to encourage schools to apply innovative teaching methods, to develop communication skills, skills of cooperation and self-dependent learning, to promote the use of information and communication technologies in the process of music education.

In the survey the respondents were also inquired about the assessment of the learners' achievements, the data obtained are analysed in Table 5.

Table 5. Assessment: insights into how to improve the teacher's pedagogical activity (in per cent)

\begin{tabular}{|l|c|c|c|}
\hline \multicolumn{1}{|c|}{ Statements } & Agree & $\begin{array}{c}\text { Partially } \\
\text { agree }\end{array}$ & Disagree \\
\hline $\begin{array}{l}\text { The assessment criteria are well known and } \\
\text { understandable for the learners }\end{array}$ & 84 & 13.4 & 1.3 \\
\hline $\begin{array}{l}\text { I often praise and encourage the learners for their good } \\
\text { performance }\end{array}$ & 95.8 & 4.2 & 0 \\
\hline $\begin{array}{l}\text { I apply unanimous assessment criteria for the learners' } \\
\text { progress and musical achievements }\end{array}$ & 77.1 & 20.3 & 1.3 \\
\hline $\begin{array}{l}\text { I compile a plan of tasks for assessment for a learning } \\
\text { cycle }\end{array}$ & 34.3 & 56.2 & 8.5 \\
\hline $\begin{array}{l}\text { I regularly evaluate musical achievements of } \\
\text { the learners by recording their progress }\end{array}$ & 61.1 & 35.9 & 2.6 \\
\hline The evaluation is commented and justified & 77.8 & 20.3 & 1.6 \\
\hline $\begin{array}{l}\text { I encourage the learners to self-evaluate and reflect on } \\
\text { their own achievements }\end{array}$ & 67 & 30.7 & 1.6 \\
\hline $\begin{array}{l}\text { I encourage the learners to evaluate others according to } \\
\text { the criteria }\end{array}$ & 43.5 & 47.1 & 8.8 \\
\hline $\begin{array}{l}\text { I discuss instances of success and failures with my } \\
\text { colleagues }\end{array}$ & 44.8 & 49.7 & 5.6 \\
\hline
\end{tabular}


The results in Table 5 illustrate that about 96 per cent of the respondents encourage the learners for their good performance, 67 per cent encourage the pupils to self-evaluate and reflect on their own achievements. 77 per cent of the survey participants apply unanimous assessment criteria for the learners' progress and musical achievements, they give comments and justify their evaluation. 84 per cent of music teachers claim that the assessment criteria are well known and understandable for their learners. However, about 56 per cent of the respondents do not compile a plan of tasks for assessment for a learning cycle. Meanwhile, nearly a half of the survey participants indicated the option of "partially agree" dealing with the statement about discussing instances of success and failures with their colleagues. Therefore, it can be assumed that the assessment process in the music lesson aims at motivating the learners and providing possibilities for experiencing success. However, the pupil shall not be afraid to ask, make a mistake, have a different opinion form the majority. The most important prerequisite for one's better learning outcomes is the pupil's psychological security, therefore, it is essential to create a favourable climate in the classroom (Foran, 2009; Hunter, et al, 2010; Salienè, 2016).

It is well known that assessment aims at helping the learner to study successfully, develop oneself and get mature. Assessment enables the teacher to accumulate and use information about the pupil's learning experience, achievements, progress made, to foresee a learning perspective and make reasonable solutions.

Furthermore, findings of the research related to relationships, procedure and class management are discussed in Table 6.

Table 6. Relationships, procedure, class management: insights into how to improve the teacher's pedagogical activity (in per cent)

\begin{tabular}{|l|c|c|c|}
\hline \multicolumn{1}{|c|}{ Statements } & Agree & $\begin{array}{c}\text { Partially } \\
\text { agree }\end{array}$ & Disagree \\
\hline $\begin{array}{l}\text { I sometimes make rules for the behaviour in } \\
\text { the classroom together with the learners }\end{array}$ & 70.3 & 25.8 & 3.3 \\
\hline $\begin{array}{l}\text { In case of interference, I respond to the situation } \\
\text { immediately }\end{array}$ & 87.9 & 10.5 & 0.3 \\
\hline $\begin{array}{l}\text { I deal with the learners who have behavioural problems } \\
\text { individually }\end{array}$ & 42.5 & 47.4 & 8.8 \\
\hline $\begin{array}{l}\text { I manage to build a friendly relationship between my } \\
\text { pupils and me in the classroom }\end{array}$ & 78.4 & 20.6 & 0 \\
\hline $\begin{array}{l}\text { If the learners fail to understand something during } \\
\text { the lesson, they address me for help }\end{array}$ & 88.2 & 9.8 & 1.3 \\
\hline I give negative evaluation & 26.5 & 44.4 & 28.1 \\
\hline I give only positive evaluation & 20.6 & 42.2 & 35 \\
\hline
\end{tabular}




\begin{tabular}{|l|c|c|c|}
\hline \multicolumn{1}{|c|}{ Statements } & Agree & $\begin{array}{c}\text { Partially } \\
\text { agree }\end{array}$ & Disagree \\
\hline $\begin{array}{l}\text { I keep reminding the learners which kind of behaviour } \\
\text { is acceptable in the classroom }\end{array}$ & 65.4 & 30.1 & 3.6 \\
\hline I raise my voice & 11.8 & 63.4 & 23.5 \\
\hline $\begin{array}{l}\text { I try not to pay attention to problems that sometimes } \\
\text { emerge }\end{array}$ & 7.8 & 46.1 & 45.1 \\
\hline I ask those who make a noise to leave the classroom & 5.2 & 17.3 & 75.5 \\
\hline $\begin{array}{l}\text { I am punctual, I avoid "time killing”, I do not waste } \\
\text { time on unnecessary things, I prepare the materials, } \\
\text { musical instruments, etc. in advance }\end{array}$ & 76.5 & 21.9 & 0.7 \\
\hline $\begin{array}{l}\text { There appear no problems of discipline and behaviour } \\
\text { in my lessons }\end{array}$ & 29.7 & 56.9 & 12.7 \\
\hline
\end{tabular}

The analysis of the research data revealed that music teachers respond to interference in the music lesson and try to deal with such a situation (87.9 per cent). In case the learners find the lesson material or an assignment difficult to understand, they address the teacher for help during the lesson (88.2 per cent), which reveals that the relationships between the pupils and the teacher are positive (78.4 per cent). 76.5 per cent of the respondents claim that they do not waste time in the music lesson, they prepare the materials in advance, besides, 70.3 per cent state that they make rules for the behaviour in the classroom together with the learners.

The study disclosed that music teachers give approximately the same amount of positive (42.2 per cent) and negative (44.4 per cent) evaluation to their pupils. 47.4 per cent of the respondents marked the option of "partially agree" when dealing with the statement about how they address the learners who have behavioural problems. About 76 per cent of the teachers do not ask those pupils who make a noise to leave the classroom when trying to manage problematic situations during the lesson. It can be noted that about 60 per cent of the respondents claim that there appear no problems of discipline and behaviour in their lessons. Taking into consideration the results in Table 6 , it is possible to notice that the relationships, procedure, class management in the music lesson are directed towards successful and safe education and oriented towards the child's wellbeing. It is obvious that in order to make the educational process attractive and joyful it is important to select proper teaching methods, tools and topics that would enhance the learner's interest in the educational process, one's motivation to study, one's responsibility, it is essential that conditions and situations allowing the learner to experience the success of learning and performance are created.

The information provided in Table 7 illustrates the survey results that characterise learning environment in the music lesson. 
Table 7. Learning environment: insights into how to improve the teacher's pedagogical activity (in per cent)

\begin{tabular}{|c|c|c|c|}
\hline Statements & Agree & $\begin{array}{c}\text { Partially } \\
\text { agree }\end{array}$ & Disagree \\
\hline $\begin{array}{l}\text { The atmosphere in the classroom is characterized by } \\
\text { the lack of tension and fear }\end{array}$ & 79.7 & 14.1 & 5.6 \\
\hline $\begin{array}{l}\text { The predominant communication between my pupils } \\
\text { and me is characterized by mutual respect }\end{array}$ & 75.8 & 23.2 & 0.3 \\
\hline $\begin{array}{l}\text { There is no urgency in the lesson, I am patient when } \\
\text { responding to some pupils' slow pace of learning }\end{array}$ & 63.1 & 35.6 & 0.7 \\
\hline $\begin{array}{l}\text { I show understanding when reacting to mistakes of } \\
\text { the learners }\end{array}$ & 89.9 & 9.5 & 0.3 \\
\hline I have enough music textbooks in the music room & 44.4 & 36.3 & 18 \\
\hline $\begin{array}{l}\text { There are numerous teaching/learning tools received } \\
\text { through EU projects in the music room }\end{array}$ & 24.2 & 31 & 43.5 \\
\hline I also use my own visual tools in the lesson & 65.4 & 30.7 & 2.3 \\
\hline $\begin{array}{l}\text { I use a variety of tools to deliver the material } \\
\text { (computer, multimedia) during the lesson }\end{array}$ & 76.8 & 15.7 & 6.2 \\
\hline I use a Smart Board in the lesson & 6.5 & 10.8 & 80.7 \\
\hline $\begin{array}{l}\text { I use a variety of music computer programmes in } \\
\text { the lesson (Sibelius, Magix Music maker, The Ejay, Groovy } \\
\text { Music, Auralia). }\end{array}$ & 14.4 & 37.6 & 46.4 \\
\hline $\begin{array}{l}\text { I use non-traditional teaching/learning environments } \\
\text { (going to concerts, on educational excursions) }\end{array}$ & 35.3 & 50.3 & 13.4 \\
\hline $\begin{array}{l}\text { In the music lesson we most often perform the following } \\
\text { activities: } \\
\text { Sing, }\end{array}$ & 78.4 & 20.6 & 0.3 \\
\hline Play various musical instruments, & 46.7 & 45.4 & 5.2 \\
\hline Rhythm, & 67 & 31.4 & 0.7 \\
\hline Solfeggio, & 39.5 & 45.4 & 12.7 \\
\hline Create music, & 25.2 & 56.5 & 16.3 \\
\hline Improvise, & 38.2 & 59.9 & 6.9 \\
\hline $\begin{array}{l}\text { Participate in discussions to analyse and evaluate } \\
\text { the musical pieces we listened to, }\end{array}$ & 66 & 29.1 & 3.3 \\
\hline Participate in some extra musical activities at school, & 70.3 & 26.1 & 2 \\
\hline Participate in musical events in the city. & 55.6 & 35.9 & 6.2 \\
\hline $\begin{array}{l}\text { Working conditions at school are good (music room, } \\
\text { safe environment, suitable working hours, good } \\
\text { infrastructure, etc.) }\end{array}$ & 53.9 & 36.6 & 8.2 \\
\hline $\begin{array}{l}\text { The school allocates sufficient funds to equip the music } \\
\text { room with teaching/learning tools }\end{array}$ & 33 & 45.4 & 19.9 \\
\hline $\begin{array}{l}\text { We can move freely, rearrange the desks, sit in a circle, } \\
\text { etc. in the music room }\end{array}$ & 49 & 31.7 & 17.3 \\
\hline
\end{tabular}


Favourable learning environment and mutual collaboration enable the learner to find intrinsic motivation to study and master the information received during the lesson. The survey participants emphasize that they show understanding when reacting to mistakes of the learners (89.9 per cent), moreover, a mutual respect is predominant in the communication between the teacher and pupils (75.8 per cent). Furthermore, the atmosphere in the music lesson is characterized by the lack of tension and fear (79.7 per cent). The majority of the respondents (76.8 per cent) indicate that they employ various teaching tools in the music lesson. Nevertheless, it is worth mentioning that more than 80 per cent of the teachers do not use Smart Board in the classroom, 46.4 per cent do not make use of a variety of music computer programmes and 43.5 per cent of the respondents claim that teaching/learning tools are not sufficient in the music room (received through EU projects). Thus, it can be assumed that the insufficient use of modern technology makes the music lesson less attractive for a contemporary learner.

The research also aimed at investigating the activities that prevail in the music classroom. The analysis of the survey results disclosed that singing (78.4 per cent), rhythm (67 per cent) and participation in discussions to analyse and evaluate the musical pieces the pupils listened to (66 per cent) are the predominant ones. Besides, the teachers also encourage their pupils to participate in extra curriculum activities at school (70.3 per cent). Less attention is given to solfeggio (the option of "partially agree" was marked by 45.4 per cent of the respondents). The survey participants affirm that working conditions at their school are favourable (53.9 per cent), whereas only 33 per cent of them agree that their school allocates sufficient funds to equip the music room with teaching/learning tools. The teachers agree (49 per cent) that it is possible to organize various activities in their classroom since they can move freely and rearrange the desks. The research confirms that the learning environment should be creative, since it fosters the learners' innovative thinking and flexibility, it preconditions the ability to envisage and notice problems, to think and experiment. When experiencing the joy of creativity, a positive approach to novelty is developed as well as imagination, sensitivity, openness to oneself and others, moreover, the learners are encouraged to participate in a variety of activities so that they could satisfy their needs for self-expression.

\section{Conclusions}

The research revealed that achievements in innovative educational research direct the teacher towards successful participation in the processes of music education development and dissemination. The research data 
allow to conclude that the activity of the teacher today is based on the following: the content of the lesson is planned considering the abilities, developmental peculiarities of a specific class and applying appropriate educational methods; information for the lesson is collected from various information sources; critical thinking, communication skills and creativity are promoted in the lesson taking into account the learners' interests and needs; evaluation of school learners' achievements encourage them to learn and reflect, assessment criteria are understood and accessible to everyone according to abilities, etc.

Having considered the opinion of the teachers in the survey, the following aspects of the teachers' activity that focus on the success and wellbeing of learners can be highlighted: efficiency of school students' learning is improved by integration of new technologies, video and audio equipment in a lesson; continuous search for ways of curriculum improvement; efficient application of teaching aids in a lesson; differentiation of assignments and possibility for its choice; attention to interdisciplinary integration; inclusive education; variety of material resources; needs for teachers' professional development, etc.

\section{References}

Abramauskienė, J., Kirliauskienė, R. (2014). Muzikos pedagogo profesijos pasirinkimo motyvai ir jų kaita studijų metu [Motives for Choosing Music Teacher's Profession and Their Change in the Course of Studies]. Pedagogika, 1(113), 45-57.

Bitinas, B. (2006). Edukologinis tyrimas: sistema ir procesas [Educational Research: System and Process]. Vilnius: Kronta.

Davidova, J., Zavadska, G., Rauduvaite, A. \& Chuang, M.-J. (2017). Strategies for the development of 6-8-year-old children's breathing for singing. Pedagogika, 125(1), 111-121.

Dèl mokytojo profesijos kompetenciju aprašo patvirtinimo. (2007). Lietuvos Respublikos švietimo ir mokslo mininstro įsąkymas $2007 \mathrm{~m}$. sausio $15 \mathrm{~d}$. Nr. ISAK-54. [Descriptor of Professional Competences of a Teacher (2007)] https://e-seimas.lrs.lt/portal/legalAct/ 1t/TAD/TAIS.291726.

Dèl pedagogu rengimo modelio aprašo patvirtinimo. (2017). Lietuvos Respublikos švietimo ir mokslo ministro isąkymas. $2017 \mathrm{~m}$. rugsejo $14 \mathrm{~d}$. Nr. V-683. [On the Approval of the Description of Teacher Education Model (2017)] https://e-seimas.lrs.lt/portal/ legalAct/lt/TAD/01388c40998611e78d46b68e19efc509?jfwid = 5w7avl4go.

Dèl reikalavimu mokytojų kvalifikacijai aprašo patvirtinimo. (2014). Lietuvos Respublikos Švietimo ir mokslo ministro įsąkymas $2014 \mathrm{~m}$. rugpjūčio 29 d. Nr. V-774. [On the Approval of the Description of Requirements for Teacher Qualification (2014)] https://e-seimas.lrs.lt/portal/legalAct/lt/TAD/7367f7d02fbf11e4b487eaabe28831e8/ dhNINMnisK.

Education and training in Europe 2020. Accessed at: https://abdigm.meb.gov.tr/projeler/ ois/009.pdf. 
Foran, L. M. (2009). Listening to Music: Helping Children Regulate Their Emotions and Improve Learning in the Classroom. Educational horizons, 51-58.

Girdzijauskas, A. (2012). Aukštesniujų klasių mokinių dorovinès kultūros ugdymas muzikine veikla [Development of Moral Culture of Higher-Class Pupils through Musical Activity]. Klaipèda: KU leidykla.

Girdzijauskienè, R. (2008). Muzikos mokytojo profesinès kompetencijos ypatumai [Peculiarities of Music Teacher's Competency]. Tiltai, 37, 5-12.

Hallam, S. (2010). The power of music: Its impact on the intellectual, social and personal development of children and young people. International journal of music education, 28(3), 269-289.

Hedden, D. (2017). Lessons from Lithuania: A pedagogical approach in teaching improvisation, International Journal of Music Education, 35(2), 289-301.

Heimonen, M., Herbert, D. G. (2019). Advancing music education via Nordic cooperation: equity and equality as central concepts in Finland. In Herbert D. G., Hauge T. B. (Eds.), Advancing Music Education in Northern Europe (pp. 119-140). London \& New York: Roputledge.

Höfer, F. (2017). Fostering Creativity through Popular Music in Music Education, European perspectives on music education 7. Creativity and innovation. In R. Girdzijauskiene, M. Stakelum (Eds.), 147-164.

Hunter, P. G., Schellenberg, G. E., Schimmack U. (2010). Feelings and Perceptions of Happiness and Sadness Induced by Music: Similarities, Differences, and Mixed Emotions. Psychology of Aesthetics, Creativity, and the Arts, 1, 47-56.

Johnsos, C. D., Matteheus, W. K. (2017). Experienced general music teachers' instructional decision making. Interpersonal Journal of music education, 35(2), 189-201.

Lasauskienè, J. (2010). Muzikos mokytojo veikla ir kompetencijos [Activity and Competences of a Music Teacher]. Vilnius: VPU leidykla.

Powell, R. S., Parker, C. E. (2017). Preservice music teachers' descriptions of successful and unsuccessful teachers. Journal of music teachers' education, 26(3), 27-37.

Pradinio ir pagrindinio ugdymo bendrosios programos [General Programmes of Primary and Basic Education]. (2009). Vilnius: Švietimo aprūpinimo centras.

Rinkevičius, Z. (2002). Muzikinis mastymas ir jo ugdymas mokykloje [Musical Thinking and Its Development at School]. Klaipeda: Spindulys.

Sakadolskienè, E. (2017). Ne vien žinios ir gebejjimai: transformacijos per mokytojo socializaciją ir tapatybès ugdymą [Not Just Knowledge and Skills: Transformations in Teacher Socialization and Identity]. Acta Paedagogica Vilnensia, 38, 42-57.

Salienė, V. (2016). Mokytojų rengimas Lietuvoje: iššūkiai ir galimybès [Teacher Training in Lithuania: Challenges and Opportunities] Ganatleba, Gruzijos technikos universitetas, 27-37.

Šečkuvienė, H. (2004). Vaiko muzikiniu gebëjimu ugdymas [Development of Musical Skills of Children]. Vilnius: VPU leidykla.

Sepp, A., Laanemets, U., Kiilu, K. (2019). Bridging the past, present and future in Estonia music education. In Herbert, D. G., Hauge, T. B. (Eds.), Advancing Music Education in Northern Europe (pp. 141-154). London \& New York: Roputledge. 
Strakšienė, D. (2004). Mokytojo tipas - bendradarbiavimo muzikos pamokoje prielaida [Teacher's Type - Precondition for Cooperation in the Music Lesson]. Meninis ugdymas, 4, 143-149.

Valstybine švietimo 2013-2022 metu strategija. (2014) [The National Education Strategy for the Period of 2013-2022, 2014]. Vilnius: Lietuvos Respublikos Švietimo ir mokslo ministerija.

Vitkauskas, R. (2001). Muzikos mokytojas: jo savirealizacijos problema [Music Teacher: Problem of One's Self-realization]. Pedagogika, 55, 108-113.

Vitkauskas, R., Abramauskienė, J., Barisas, K., Kirliauskienė, R., PalubinskienèTarnauskaitè, V. (2012). Bendrasis muzikinis ugdymas Lietuvoje: raida ir kryptys [General Music Education in Lithuania: Development and Trends]. Vilnius: LEU leidykla.

Žydžiūnaitè, V., Sabaliauskas, S. (2017). Kokybiniai tyrimai: principai ir metodai [Qualitative Research: Principles and Methodology]. Vilnius: Vaga. 